\title{
Gerald Raunig
}

Rzecz-pospolita. Nowe maszyny tego, co wspólne

Pierwszy tom trylogii Michaela Hardta i Toniego Negriego był teoretycznym wydarzeniem, a zarazem dyskursywną maszyną ruchu alterglobalistycznego. Sprzężenie Imperium z rozwijającym się ruchem krytyki globalizacji w żadnym wypadku nie polegało jednak na prostym, linearnym powiązaniu. Propozycja wyłożona w Imperium nie polegała na nakreśleniu planu dla walk przełomu stuleci, na stworzeniu teoretycznego modelu, który powinny przyjąć nowe ruchy społeczne rewolucyjnej wielości. Z drugiej strony, książka ta nie była też po prostu wczesną interpretacją oraz historycznym zaszeregowaniem tej ambiwalentnej figury politycznej i społecznej. Wręcz przeciwnie, obie te maszyny, dyskursywna maszyna wokół Imperium i maszyna społeczna, która formowała się od końca lat dziewięćdziesiątych w protestach przeciwko MFW, Bankowi Światowemu oraz G7, wytwarzały nieustannie efekty wzajemnego nakładania się, przecinania i wymiany.

Dziesięć lat później Hardt i Negri jeszcze raz odpalili ową maszynę za pomocą nowego pojęcia o dużej wadze - to, co wspólne, dobro wspólne ma dziś istotnie dużo silniejszy impakt polityczny i historyczno-filozoficzny niż oba pojęcia tworzące tytuł poprzednich tomów serii: Imperium i Wielość. Genealogiczne linie tego pojęcia odsyłają do prawicowych dyskursów o wspólnocie, jak i, a raczej przede wszystkim, różnych debat na lewicy wokół pytań o communitas, wspólnoty (komuny) oraz komunizm. Strategia nie mająca na celu wyciszenia napięcia wynikającego ze splotu tych dwóch pespektyw, lecz raczej dążąca do uwzględnienia post- marksistowskich i poststrukturalistycznych pozycji autorów oraz wyjścia poza nie, decyduje o sile Rzeczy-pospolitej.

Jak obaj autorzy piszą we wstępie, przez to, co wspólne, rozumieją oni z jednej strony „wspólne bogactwo materialnego świata - powietrze, wodę, owoce ziemi i wszelkie dary natury - o których wiele klasycznych europejskich tekstów politycznych głosiło, że jest dziedzictwem całej ludzkości ${ }^{1}$. Z drugiej strony, i jest to aspekt podkreślany przez Negriego i Hardta, dobro wspólne obejmuje także „te rezultaty społecznej produkcji, które są niezbędne dla społecznych interakcji oraz dalszej produkcji, takie jak wiedza, języki, kody, informacja, afekty itd.”2. W tej drugiej perspektywie pod pojęciem dobra wspólnego rozumie się praktyki interakcji, troski i opieki, koegzystencji we wspólnym świecie, czyli te praktyki, które nie pozwalają na ujmowanie ludzkości jako oddzielonej od natury, czy to poprzez logikę wyzysku, czy też ochrony.

$\mathrm{Na}$ obu tych poziomach można rozumieć Rzecz-pospolita jako domknięcie trylogii, które koreluje z wybrzmieniem ruchu alterglobalistycznego; swego rodzaju dalszy rozbieg, mający na celu zaktualizowanie teorii postoperaizmu i wzbogacenie jej o inne nurty (w tym wypadku chodzi przede wszystkim o koncepcje feministyczne, queerowe i postkolonialne). Mówiąc o końcu ruchu alterglobalistycznego można jednak dać się zwieść nazbyt uproszczonej idei cykli ruchów społecznych i przesłonić ich rozmaite przejścia i trajektorie (możliwe, że już od roku 1968, z pewnością jednak od 
lat dziewięćdziesiątych). W przeciwieństwie do tego należałoby, w paraleli do perspektywy podkreślającej ciągłość ruchów zapatystycznych, forów społecznych, ruchów krytycznych wobec globalizacji, a także tych ukazujących postępującą prekaryzację czy mających za swój cel okupację, dyskredytować dyskurs o końcu jako patetyczną fantazję o przełomie. Rzecz-pospolitą można więc ująć nie tylko jako zakończenie trylogii, ale być może także jako początek nowego rodzaju powiązanej ze wszystkimi tymi ruchami wysokiej koniunktury na walki społeczne.

Oprócz obu wymienionych we wstępie zasadniczych wymiarów dobra wspólnego, na kartach całej książki można dostrzec jeszcze jeden jego aspekt, będący właśnie tematyzacją kwestii sprzężenia tych pojedynczych prądów: to, co wspólne, jako samoorganizacja relacji społecznych. Nie rozumie się jej tu w żadnym razie jako prostego faktu empirycznego, ani też jako naturalistycz- nego automatyzmu, lecz jako polityczny projekt instytucji dobra wspólnego. Owo ustanowienie instytucji tego, co wspólne, zakłada z jednej strony, że dobro wspólne nie może być rozumiane jako bycie-razem, lecz jako stawanie-się-razem, jako produkcja tego, co wspólne. Instytucjonalizacja implikuje również to, że dobro wspólne i pojedynczości są ko-emergentne; są nie tylko kompatybilne, lecz nawzajem się konstytuują.

O takie właśnie ustanowienie i instytucjonalizację dobra wspólnego chodzi w ruchach okupacyjnych roku 2011. W całej swej różnorodności okupacje od Tunisu po Tel Aviv, od Kairu po Oakland, od greckich powstań po hiszpański ruch M-15, od Occupy Wall Street po Occupy Moscow, wskazują na podobieństwa, które zbiegają się we wspólnych eksperymentach z prekarnymi sposobami życia, z orgiastycznymi formami organizacji oraz apropriacji czasu i przestrzeni, w sensie produkcji nowych maszyn dobra wspólnego.

Przetożyt Mikotaj Ratajczak

1 M. Hardt, A. Negri, Commonwealth, Cambridge MA 2009, s. VII.

2 Tamże. 
GERALD RAUNIG jest filozofem i teoretykiem sztuki. Pracuje na Zürcher Hochschule der Künste (Akademia Sztuk Pięknych w Zurychu) i eipcp w Wiedniu (European Institute for Progressive Cultural Policies; Europejski Instytut Progresywnych Polityk Kulturowych). Jeden $\mathrm{z}$ redaktorów wielojęzycznego czasopisma sieciowego Transversal oraz austriackiego periodyku poświęconego radykalnie demokratycznej polityce kulturowej, Kulturrisse. Koordynator wielu transnarodowych badań pod auspicjami eipcp, w tym m.in. Creating Worlds, śledzącego związek między produkcją sztuki i produkcją wiedzy w kontekście kapitalizmu kognitywnego. Autor m.in: A Thousand Machines: A Concise Philosophy of the Machine as Social Movement (2010); Art and Contemporary Critical Practice: Reinventing Institutional Critique (redakcja naukowa, razem z Genem Ray'em) (2009); and Art and Revolution: Transversal Activism in the Long Twentieth Century (2007). Mieszka i pracuje w Zurychu.
Dane adresowe autora:

Zürcher Hochschule der Künste

Ausstellungsstrasse 60

8005 Zurich

Switzerland

e-mail: gerald.raunig@zhdk.ch

Cytowanie:

G. Raunig, Rzecz-pospolita. Nowe maszyny tego, co wspólne, „Praktyka Teoretyczna” nr 4/2011, http://www.praktykateoretyczna.pl/PT nr4 2011 Commonwealth/17.Raunig. pdf (dostęp dzień miesiąc rok) 